\title{
Influence of Nitrogenous Fertilizers on Guinea Grass Yield and Carrying Capacity in Lajas Valley
}

\author{
L. Rivera-Brenes, E. N. Colón-Torres, F. Gelpi, and J. Torres-Más ${ }^{1}$
}

INTRODUCTION

The Lajas Valley is a semiarid section in the southwestern corner of Puerto Rico. The arable land comprises around 35,000 acres, of which around two-thirds are dedicated to cattle raising, especially dairy cattle. Of the land in pasture only one-third is improved and cultivated pasture (2). ${ }^{2}$

Guinea grass, Panicum maximum, is the most important grass in the area. It is very resistant to the dry conditions prevailing and produces an abundance of good palatable roughage.

Generally speaking, pasture management is poor in the Valley. The prevailing climatic conditions are blamed for this neglect. Guinea grass is seeded once and from there on very little care is given. Fertilization is seldom practiced, as many farmers do not believe that fertilizer applications are profitable. Continuous grazing is the only system; overstocking and overgrazing are seen everywhere.

The weed problem is serious in the Valley. Pajon, Andropogon annuatus, is the predominant weed, which, together with paragüita, Chloris inflata, and other weeds, competes favorably in the field with Guinea. When Guinea grass is neglected, as indicated above, these weeds take over and eliminate it in a very short time. Some farmers claim, though, that Pajón is a good pasture grass which can withstand the most severe drought and treatment, being in this respect better than Guinea grass.

Actually the Government of the Commonwealth is establishing an irrigation district for the Valley. The district will cover more than 20,000 acres and a very drastic change in the agricultural pattern of the Valley lands is expected in a short time.

With the establishment of the Lajas Substation in Lajas Valley, research on animal husbandry and on pasture improvement and evaluation for the area were started. As Guinea grass has been the most important prevailing forage in the region, it was decided to seek information on its performance under different management conditions. Some final and some preliminary results are presented in this paper. This is the final report for

1 Head, Animal Husbandry Department; Assistant Animal Husbandman; Assistant Animal Husbandman; and Research Assistant, respectively, Agricultural Experiment Station, University of Puerto Rico, Río Piedras, P.R.

2 Italic numbers in parentheses refer to Literature Cited, p. 247. 
Guinea grass fertilized with 200 pounds of ammonium sulfate applied per acre every 4 months, and for nonfertilized Guinea grass. It also presents a preliminary report on Guinea grass fertilized with 400 pounds of ammonium sulfate every 4 months, for which data are available for only 2 years.

\section{LITERATURE REVIEW}

Boneta (1) studied the adaptability to different regions of the Island of several new strains of Guinea grass developed by the Plant Breeding Department of this Station.

Carrying capacity, as well as pounds of beef per acre, were determined for Guinea grass under different fertilizer treatments and rotational grazing in the northern humid section of the Island $(3,4,5)$.

Results of the grazing trials with Guinea grass not fertilized at Río Piedras, where rainfall is over 60 inches a year, showed a carrying capacity of 0.42 . The net gain in weight per acre per year was 185 pounds, plus the equivalent of 626 pounds of TDN from the residue clipped per acre. Further grazing trials in which Guinea grass received an initial application of 1,000 pounds of $10-10-5$, and 200 pounds of ammonium sulfate every 4 months thereafter raised the carrying capacity to 0.9 . The net gain in weight per acre per year was 515 pounds, plus the equivalent of 2,132 pounds of TDN from the residues clipped per acre.

Guinea grass has been submitted to further grazing experiments, but in combination with tropical kudzu $(4,5,7)$. Results of the grass-legume combination have been very satisfactory, a carrying capacity of 1.42 having been obtained with an average net gain in weight per year of 930 pounds per acre.

Yield per acre as soilage at different cutting intervals has been also determined at Río Piedras $(6)$. The yields per acre per year at 40-, 90-, and 120-day cutting intervals were as follows: 10,7 , and 7 tons of dry matter, respectively.

\section{PROCEDURE}

The procedure followed in this study was similar to that used for previous experiments performed at the Main Station (8). The trial consisted originally in the comparison of three treatments with Guinea grass: First, the combination of Guinea grass with tropical kudzu; second, Guinea grass fertilized with 200 pounds of ammonium sulfate ( 40 pounds of nitrogen) every 4 months; and third, Guinea grass with no fertilizer at all.

The field was seeded to Guinea grass by the end of the year 1951. The kudzu was planted in the corresponding plots. A very good grass stand was obtained, but the first treatment was eliminated after the impossibility of establishing the legume. Two years after the experiment was 
started, another treatment was introduced. This consisted of applications of 400 pounds of ammonium sulfate (80 pounds of nitrogen) per acre every 4 months to the plots corresponding to the grass-legume combination.

Difficulties with legume had been expected, as the findings of Telford (8) at Mayagüez were known beforehand; he was not able to grow kudzu successfully in places with less than $\mathbf{5 0}$ inches of rainfall. The combination was tried at Lajas, however, since Lajas is in that borderline. The experiment was established in a Santa Isabel clay soil, which is representative of the Valley, with no irrigation.

Eight- to twelve-month-old crossbred dairy Holstein $X$ Native and Brown Swiss X Native heifers were used. The groups were balanced as to age, total weight, and breed. Occasionally some Guernsey heifers were used, distributed evenly among the groups.

The put-and-take system was followed, so that all roughage was con-

TABLE 1.-Net gain in weight of animals, in pounds per acre per year, for Guinea grass under the three fertilizer treatments

\begin{tabular}{l|c|c|c|c}
\hline Treatment & First year & Second year & Third year & Fourth year \\
\cline { 1 - 3 } G. 0 & 197 & 336 & 522 & 308 \\
G. 200 & 407 & 507 & 569 & 635 \\
G. 400 & - & - & 770 & 816 \\
\hline
\end{tabular}

sumed by the animals. In what follows the treatments will be referred to as G. 400 , G. 200 , and G. 0 .

\section{RESULTS AND DISCUSSION}

Table 1 presents the gains in weight per acre per year for the animals on the Guinea grass under the three fertilizer treatments.

The statistical analyses vere made considering the differences between treatments, between years, and the interaction of years and treatments. A separate analysis was made for the last 2 years of G. 0 and G. 200 because there was a species shift during those two years in the treatment G. 0 from Guinea grass to Pajón (Andropogon annuatus) of over 90 percent.

The 4-year average gains in weight of the animals, in pounds, for the G. 0 and G. 200 treatments are presented in the following tabulation:

\section{Treatment}

G. 0

G. 200

I. S. D. 0.05

L. S. D. 0.01
Mean gain in sueight

341

530

35

49 
G. 200 was superior to G. 0 in the 4-year trial. Differences were highly significant.

The differences between grass-years, table 1, were also highly significant. The least significant differences were 69 and 97 pounds for the 5and 1-percent levels, respectively. The last 2 years were significantly better than the first two for both treatments.

On comparing the first two years with the last two years of treatment G. 0 the possibility suggested itself that the Pajón might have performed better than the Guinea grass with no nitrogen, but after the data were analyzed the difference had to be attributed to an effect of year. The same situation was found in treatment G. 200. This is more clearly seen when the average animal gain in weight per acre per year for the two treatments together is analyzed in the following tabulation:

\begin{tabular}{lc}
\multicolumn{1}{c}{ Year } & $\begin{array}{c}\text { Grain in woight in pounds } \\
\text { per acre per year }\end{array}$ \\
1st & 302 \\
2d & 422 \\
3d & 546 \\
4th & 471 \\
L. S. D. 0.05 & 49 \\
L. S. D. 0.01 & 69
\end{tabular}

The first 2 years of treatment G. 400 were the last for treatments G. 0 and G. 200. Separate statistical analyses were made for this period.

The following tabulation shows the mean animal gain in weight for the three treatments per acre per year:

\begin{tabular}{lc}
\multicolumn{1}{c}{ Year } & $\begin{array}{c}\text { 3-trealment mean in pounds } \\
\text { per acre per year }\end{array}$ \\
3d & 620 \\
4th & 586 \\
L. S. D. 0.05 & 72
\end{tabular}

'The difference was not significant. The effect of year was the same for all treatments.

The difference between treatments was highly significant, as shown in the following tabulation giving the mean animal gains in weight for the third and fourth years:

$\begin{array}{lc}\quad \text { Treatment } & \text { Gain in weight } \\ \text { G. } 400 & 794 \\ \text { G. } 200 & 602 \\ \text { G. } 0 & 415 \\ \text { L. S. D. } 0.05 & 88 \\ \text { L. S. D. } 0.01 & 134\end{array}$

Guinea grass with 400 pounds of ammonium sulfate per acre every 4 months (G. 400) was significantly superior to the application of 200 pounds 
of the same fertilizer at the same intervals (G. 200). Guinea with no fertilizer (G. 0) was the lowest in yield. In the last 2 years of treatment G. 0 the plots were over 90-percent Pajón. If we point out here that this grass is considered by many farmers as a very poor weed, the gains in weight obtained per acre are really surprising and revealing. It should also be noted that the species shift in the zero-fertilizer treatment was over 90 percent while in the fertilized plots the invasion of other grasses and weeds was not over 10 to 15 percent, as calculated by inspection, considering all plots. Fertilization favored the stand of Guinea grass, not counting other beneficial effects to the soil itself.

The summary of the grazing results is presented in table 2 . It includes the 4 years of G. 200 , G. 0 , and 2 years of G. 400 .

The chemical analyses of the grass samples representing the three treatments are given in table 3 . Although these analyses present some differences, they are not large enough to show the real differences between

TABLE 2.-Grazing results for the different Guinea grass treatments

\begin{tabular}{l|r|r|c|c|c|c|c}
\hline \multicolumn{1}{|c|}{ Treatment } & $\begin{array}{c}\text { Days in } \\
\text { treatment }\end{array}$ & $\begin{array}{c}\text { Standard } \\
\text { cowv-days }\end{array}$ & $\begin{array}{l}\text { Carrying } \\
\text { capacity }\end{array}$ & $\begin{array}{c}\text { Heifers } \\
\text { per acre } \\
\text { per day }\end{array}$ & $\begin{array}{c}\text { TDN } \\
\text { per day } \\
\text { per acre }\end{array}$ & $\begin{array}{c}\text { Heifer- } \\
\text { days }\end{array}$ & $\begin{array}{c}\text { Gain in } \\
\text { weight } \\
\text { per acre } \\
\text { per year }\end{array}$ \\
\hline & Number & & Unils & Number & & Namber & Pounds \\
2 years, G. 400 & 582 & 694.48 & 1.19 & 2.553 & 19.09 & 1,485 & 793.80 \\
4 years, G. 200 & 1,193 & 998.97 & .837 & 1.899 & 13.40 & 2,267 & 529.67 \\
4 years, G. 0 & 1,193 & 665.17 & .558 & 1.459 & 8.92 & 1,741 & 341.00 \\
\hline
\end{tabular}

the treatments. The samples were taken monthly and most of the time the known boosting effect of nitrogen fertilization on protein content, had passed. Of course, the effect of the fertilizer on yields may be clearly seen in table 2.

The average rotational intervals were as follows: For the first year, 10 days; for the second, 9 ; for the third, 9.4; and for the fourth year 6.5 days. Rotations were made as judged convenient to prevent overgrazing.

Lajas Valley is not as dry as is commonly believed. People speak of 35 inches of rainfall a year or less. It is true that once every 10 to 15 years there is a very prolonged dry spell, but normally in the Valley the rainfall is sufficient for pasture grasses with only one or two really dry months. This may be seen in table 4, presenting the rainfall data from 1952 to 1956.

No wind data for the experimental period are available, but the region is quite windy. An almost constant dry wind blows over it which might be responsible for a high rate of evaporation. This is a factor that should be considered in further research. 
The returns above cost of fertilizer and the comparison between treatments give a much better idea of the importance of fertilization. This

TABLE 3.-Percentage chemical analyses of Guinea grass under the experimental treatments

\begin{tabular}{l|c|c|c|c|c|c|c}
\hline \multicolumn{1}{c|}{ Trealment } & Year & Samples & Protein & Ash & Fat & Fiber & N.F.C. \\
\cline { 2 - 3 } \cline { 2 - 5 } G. 0 & 1953 & 14 & 6.89 & 11.67 & 1.61 & 30.34 & 49.49 \\
& 1954 & 14 & 7.47 & 12.87 & 1.50 & 27.90 & 49.82 \\
& 1955 & $6^{1}$ & 7.31 & 11.85 & 1.67 & 31.15 & 48.02 \\
& 1956 & $3^{2}$ & 10.69 & 11.99 & 2.14 & 29.19 & 45.99 \\
G. 200 & 1953 & 15 & 5.96 & 11.29 & 1.33 & 32.55 & 49.02 \\
& 1954 & 15 & 10.45 & 12.37 & 1.67 & 26.81 & 49.99 \\
& 1955 & $6^{1}$ & 9.07 & 11.53 & 1.78 & 30.39 & 47.23 \\
& 1956 & $6^{1}$ & 12.37 & 12.43 & 2.34 & 28.37 & 44.49 \\
G. 400 & 1955 & $6^{1}$ & 12.47 & 10.91 & 1.98 & 29.71 & 44.93 \\
& 1956 & $6^{1}$ & 13.78 & 11.40 & 2.33 & 29.21 & 43.28 \\
\hline
\end{tabular}

1 Each one of these 6 samples represents a composite sample of 4 or 5 monthly samples per block.

2 Each sample is a composite of all monthly samples for each block.

TABLE 4.-Rainfall dala for Lajas Valley, in inches, by year and month, 1952-561

\begin{tabular}{l|r|r|r|r|r}
\hline \multicolumn{1}{c|}{ Month } & \multicolumn{1}{c|}{1952} & \multicolumn{1}{c|}{1953} & \multicolumn{1}{c|}{1954} & 1955 & \multicolumn{1}{c}{1956} \\
\cline { 2 - 3 } & 1.10 & 1.48 & 3.44 & 0.45 & 4.19 \\
January & 2.06 & .95 & 4.84 & 1.28 & .24 \\
February & 1.96 & 4.28 & 1.53 & 2.53 & 2.88 \\
March & 4.57 & 2.14 & 9.19 & 2.01 & 4.83 \\
April & 2.45 & 2.71 & 2.81 & 5.24 & 4.56 \\
May & 1.19 & 5.44 & 3.09 & 3.37 & 5.28 \\
June & 2.68 & 4.79 & 3.51 & 5.81 & 4.14 \\
July & 5.39 & 8.58 & 7.16 & 6.09 & 3.62 \\
August & 14.90 & 2.81 & 10.22 & 9.20 & 3.59 \\
September & 5.99 & 6.10 & 6.60 & 6.16 & 10.45 \\
October & 3.40 & 5.56 & 3.97 & 4.10 & 6.08 \\
November & 1.03 & 2.39 & 2.94 & 3.12 & 3.38 \\
December & 46.72 & 47.21 & 58.30 & 51.36 & 58.44 \\
\hline Total & & &
\end{tabular}

1 Data taken from the Jajas Substation records.

management practice is seldom used in Lajas Valley. The only reason given is that fertilizer is not used efficiently during the prolonged dry periods prevailing in the region. This assumption, as shown here, is unwarranted. 
At 16 cents a pound of meat on hoof, the gross returns per acre per year were as follows: G. $0, \$ 56.56$; G. $200, \$ 84.80$; G. $400, \$ 127$.

Fertilizer cost per acre per year for G. 200 was $\$ 21$ and for G. $400, \$ 42$. This includes cost of application. The return above cost of fertilizer was $\$ 63.80$ for G. 200 and $\$ 85$ for G. 400 . When G. 0 and G. 200 were compared as with returns above cost of fertilizer, the difference was of only $\$ 9.34$, while between G. 400 and G. 0 the excess return was $\$ 34.44$.

Not counting the beneficial effects of fertilization on the soil and plant, respectively, apparently 200 pounds of ammonium sulfate per acre per year is not enough to bring a satisfactory return under the conditions under which the experiment developed.

\section{SUMMARY AND CONCLUSIONS}

The Lajas Valley is a semiarid region located in the southwestern corner of the Island. Annual rainfall fluctuates from 40 to 60 inches with rather prolonged dry spells.

Guinea grass is the prevailing and most important pasture forage. Very little or no fertilizer at all is used and, generally speaking, the grazing management is poor.

In 1952, an experiment was started with Guinea grass submitted to different fertilizer treatments, under rotational grazing. A randomized-block design already described in another paper ( 3 ) was used and each treatment of 0,40 , and 80 pounds of nitrogen per acre was applied as ammonium sulfate every 4 months was replicated three times. Results obtained indicate that fertilization pays even in this relatively dry section of the Island.

The average gains in weight per acre per year were as follows: 794 pounds for the 400-pound ammonium sulfate treatment, 530 pounds for the 200, and 341 pounds for the zero-fertilizer treatment. The mean carrying capacities were $1.19,0.84$, and 0.56 adult head per acre, respectively. Rotational intervals ranged from 6.5 to 10 days throughout the 4 years of the experiment. The above-mentioned differences of gains in weight were statistically significant at the 1-percent level.

The returns above cost of fertilizer per acre were as follows: $\$ 85$ for the 400 -pound treatment, $\$ 63.80$ for the 200 , and $\$ 56.56$ for the zero-fertilizer treatment. According to these figures, 200 pounds of ammonium sulfate per acre every 4 months is not enough to bring a satisfactory return, since it produced a gross return of only $\$ 9.34$ as compared to zero nitrogen. The 400 -pound treatment brought a gross return of $\$ 34.44$ above that of the zero fertilizer treatment.

Fertilization favors the Guinea grass stands, permitting only a relatively slight competition from weeds. However, the weed Pajón, Andro- 
pogon annuatus, invaded the zero-fertilizer plots severely, to the extent that for the last 2 years of the experiment these plots were almost 95percent Pajón. In these last 2 years the heifers made fairly good gains on this weed, but inferior to the gains in the fertilized treatments. In view of this, Pajón will be submitted to fertilization treatments to determine its real value as a forage grass, as there is no information on this.

Although this grazing experiment continues with higher levels of nitrogen fertilization as compared to the 80 pounds of nitrogen every 4 months, the 80-pound level can be recommended as a good fertilization practice under the Lajas conditions for Guinea grass under rotational grazing.

\section{RESUMEN Y CONCLUSIONES}

El Valle de Lajas es una región semiárida localizada en la esquina suroeste de Puerto Rico.

La lluvia anual que recibe esta región fluctúa entre 40 y 60 pulgadas y son comunes los periodos prolongados de sequía.

La yerba más importante para el pastoreo es la Guinea, pero carece de una buena atención en cuanto a su manejo y abonamiento.

En el 1952 se inició un experimento en el cual predios experimentales de esta yerba Guinea se sometieron a diferentes tratamientos de abono bajo un pastoreo rotativo.

El experimento diseñado en forma de bloques al azar, el cual se describe en otro artículo (3), consistió de 3 tratamientos con sulfato amónico a razón de 0,40 y 80 libras de nitrógeno por cuerda cada 4 meses.

Los resultados de este experimento indican que el abonamiento de la yerba Guinea es lucrativo aún en regiones relativamente secas como es ésta del Valle de Lajas.

Las ganancias en peso por cuerda de los animales incluídos en este experimento fueron como sigue: 794 libras en el tratamiento de 400 libras de sulfato amónico, 530 libras en el de 200 libras y 341 libras en el tratamiento testigo sin abono. Las capacidades medias de sostenimiento fueron $1.19,0.84$ y 0.56 de cabeza de ganado adulto por acre, respectivamente, a los tratamientos mencionados. Los intervalos de pastoreo en rotación fluctuaron entre 6.5 y 10 días a través de los 4 años que duró el experimento. Las diferencias en cuanto a las ganancias en peso fueron estadísticamente significativas al nivel del 0.01 por ciento.

Los ingresos por acre sobre el costo del abono fueron los siguientes: $\$ 85$ para el tratamiento de 400 libras de sulfato amónico, $\$ 63.80$ para el de 200 libras, y 56.56 para el tratamiento testigo sin abono. De acuerdo con estas cifras, la aplicación de 200 libras de sulfato amónico por cuerda cada 4 meses no es suficiente para lograr un ingreso satisfactorio, ya que la diferencia entre la aplicación de este número de libras y la no aplicación de 
abono alguno fué sólo de $\$ 9.34$. Por otro lado, la aplicación de 400 libras del abono produjo un ingreso bruto de $\$ 34.44$ sobre lo producido por el tratamiento sin abono.

Se observó que el abonamiento de la yerba Guinea induce un mayor desarrollo de las cepas, lo cual no favorece el crecimiento desmedido de los yerbajos. Sin embargo, el yerbajo conocido por Pajón Andropogon annuatus invadió severamente los predios experimentales sin abono hasta el extremo de que durante los últimos 2 años del experimento estos predios tuvieron hasta un 95 por ciento de Pajón. También, durante los últimos dos años se observó que las novillas lograron aumentar de peso comiendo el Pajón, pero estos aumentos fueron menores comparados con las ganancias logradas en los predios abonados. En vista de ésto, el Pajón será sometido a aplicaciones de abono para asi determinar su valor real como pasto, ya que se carece de esta información.

Aunque este experimento de pastoreo continúa con niveles más altos en la aplicación de nitrógeno comparados con las 80 libras de este elemento aplicadas cada 4 meses, por ahora se puede recomendar este mismo nivel de 80 libras como una buena práctica de abonamiento en el pastoreo rotativo con yerba Guinea bajo las condiciones del Valle de Lajas.

\section{LITERATURE CITED}

1. Boneta, E., Personal communication and progress reports 1951, '52, '53 and '54, Genetics Dept., Agr. Exp. Sta., Univ. of P.R.

2. Commonwealth Department of Agriculture, Mimeographed paper "La utilización y tenencia de tierras en el Valle de Lajas”, Depto. de Agric. y Com., Neg. Econ. Agr., octubre 1952.

3. Rivera-Brenes, L., and Marchán, F. J., I: Comparison of Guinea grass, Pará grass, and Para grass-tropical kudzu as pasture crops, J. Agr. Univ. P.R. 31 (2) $180-90,1947$.

4. Rivera-Brenes, L., Marchán, F. J., and Cabrera, J. I. II: Comparison of fertilized Guinea grass, Pará grass-tropical kudzu, and tropical kudzu alone as pasture crops, J. Agr. Univ. P.R., 33 (3) 85-98, 1949.

5. -, III: Comparison of fertilized Guinea grass, Para grass-tropical kudzu, and Guinea grass-tropical kudzu as pasture crops, J. Agr. Univ. P.R. 34 (4) 309$16,1950$.

6. Rivera-Brenes, L., Technical and economic aspects of roughage production in Puerto Rico, Univ. P.R., Tech. Paper 12, Sept. 1953.

7. Rivera-Brenes, I., Cabrera, J. I., and Colón, L. F., Comparison of Guinea grasstropical kudzu, Para grass, Pangola grass, and St. Augustine grass as pasture crops in the Yabucoa valley in eastern Puerto Rico, J. Agr. Univ. P.R. 38 (2) 96-104, 1954.

8. Telford, E. A., and Childers, N. F., Tropical kudzu in Puerto Rico, Fed. Exp. Sta., Mayagüez, P.R., 1947. 